Case Report

\title{
Removal of Arsenic in Groundwater Using Fe(III) Oxyhydroxide Coated Sand: A Case Study in Mekong Delta, Vietnam
}

\author{
Lavane Kim ${ }^{1} \mathbb{D}$, Nguyen Truong Thanh ${ }^{1}$, Pham Van Toan ${ }^{1} \mathbb{D}$, Huynh Vuong Thu Minh ${ }^{2} \mathbb{D}$ and Pankaj Kumar ${ }^{3, *} \mathbb{D}$ \\ 1 Department of Environmental Engineering, Can Tho University, Can Tho City 94115, Vietnam; \\ klavane@ctu.edu.vn (L.K.); ntthanh@ctu.edu.vn (N.T.T.); pvtoan@ctu.edu.vn (P.V.T.) \\ 2 Department of Water Resources Management, Can Tho University, Can Tho City 94115, Vietnam; \\ hvtminh@ctu.edu.vn \\ 3 Institute for Global Environmental Strategies, Hayama 240-0115, Japan \\ * Correspondence: kumar@iges.or.jp; Tel.: +81-04-6855-3858
}

check for updates

Citation: Kim, L.; Thanh, N.T.; Toan, P.V.; Minh, H.V.T.; Kumar, P. Removal of Arsenic in Groundwater Using Fe(III) Oxyhydroxide Coated Sand: A Case Study in Mekong Delta,

Vietnam. Hydrology 2022, 9, 15. https://doi.org/10.3390/

hydrology 9010015

Academic Editors: David Brauer,

Nathan Howell and Ryan Bailey

Received: 7 December 2021

Accepted: 11 January 2022

Published: 13 January 2022

Publisher's Note: MDPI stays neutral with regard to jurisdictional claims in published maps and institutional affiliations.

Copyright: (c) 2022 by the authors Licensee MDPI, Basel, Switzerland. This article is an open access article distributed under the terms and conditions of the Creative Commons Attribution (CC BY) license (https:// creativecommons.org/licenses/by/ $4.0 /)$.

\begin{abstract}
Because of its threat to the quality of freshwater resources and human health, arsenic (As) pollution is important to scientific communities and policymakers around the world. The Mekong Delta, Vietnam, is one hotspot of As pollution. Its risk assessment of different environmental components has been well documented; however, very few studies focus on As removal techniques. Considering this information gap, this study aimed to investigate the performance of an innovative and low-cost treatment system using $\mathrm{Fe}(\mathrm{III})$-oxyhydroxide (FeOOH) coated sand to remove As(III) from aqueous solution. Batch and column experiments were conducted at a laboratory scale in order to study removal kinetics and efficiency. Experimental results indicated that the adsorption isotherm of $\mathrm{As}(\mathrm{III})$ on FeOOH coated sand using Langmuir and Freundlich models have high regression factors of 0.987 and 0.991 , respectively. The batch adsorption experiment revealed that contact time was approximately $8 \mathrm{~h}$ for rough saturation (kinetic test). The concentration of As(III) in effluents at flow rates of $0.6 \mathrm{~L} / \mathrm{h}, 0.9 \mathrm{~L} / \mathrm{h}$, and $1.8 \mathrm{~L} / \mathrm{h}$ ranged from $1.1 \mu \mathrm{g} / \mathrm{L}$ to $1.7 \mu \mathrm{g} / \mathrm{L}$. Results from this study indicated that $\mathrm{FeOOH}$ coated sand columns were effective in removing As(III) from water, with a removal efficiency of $99.1 \%$. Ultimately, FeOOH coated sand filtration could be a potential treatment system to reduce As(III) in the domestic water supply in remote areas of the Vietnamese Mekong Delta.
\end{abstract}

Keywords: Arsenic; FeOOH; adsorption; kinetic model; isotherm; removal efficiency

\section{Introduction}

Drinking water scarcity is becoming a serious problem in the Mekong Delta due to the combination of both water quality deterioration and extreme weather conditions. Therefore, in many localities, people are forced to use poor groundwater sources for their domestic use. Berg et al. [1] concluded that the arsenic concentration detected in the groundwater of the Mekong Delta mostly exceeds the Vietnam national technical regulation on drinking water QCVN 01/BYT, which sets the maximum permissible amount of As at $10 \mu \mathrm{g} / \mathrm{L}$. This situation poses a serious threat to human health as well as the ecosystem. Vietnam is one of the countries with the highest concentrations of arsenic in the groundwater. Previous studies have found that the concentration of As in groundwater in southern Vietnam ranges from 1 to $845 \mu \mathrm{g} / \mathrm{L}$ [1]. In the Mekong Delta, an investigation in An Giang province showed that the As concentration in groundwater was greater than $50 \mu \mathrm{g} / \mathrm{L}$ in a large number of tube wells [2]. Another study showed that As concentrations in groundwater varied from 12-106 $\mu \mathrm{g} / \mathrm{L}$ in Tra Vinh province, Vietnam [3]. According to current guidelines from both the Vietnam national technical regulation and the World Health Organization (WHO), As concentrations in drinking water should typically be less than $10 \mu \mathrm{g} / \mathrm{L}$. However, 
previous scientific studies reported that As concentrations in the Vietnamese Mekong Delta groundwater reached a maximum concentration of $1470 \mu \mathrm{g} / \mathrm{L}$ [4].

Different treatment methods can be used to remove As from water, such as nanofiltration, ion exchange, oxidation, precipitation, filtration, and adsorption. Combining the technologies of oxidation and nano-filtration has proven to be the most effective technique for eliminating As from groundwater [3]. Filtration is the most reliable and efficient technique for removing arsenic ions for household use because of its simple design, ease of operation, and low operation cost. However, the removal efficiency of conventional sand filtration systems remains unclear. Smith et al. [5] found that sand filtration technology is capable of removing $50 \%$ to $81 \%$ of total As from water. Few studies, however, have investigated low-cost filtration systems to remove heavy metals and As from water and wastewater. Le et al. [6] pointed out that materials containing iron oxide were effective in removing arsenic $(\mathrm{As})$, cadmium $(\mathrm{Cd})$, and lead $(\mathrm{Pb})$. Iron oxide-coated sand was more effective in removing arsenate than arsenite [7]. Bio-sand filters amended with iron nails showed a better removal rate of arsenic in groundwater [5]. Iron-based filters can also remove viruses in domestic water [8].

Using an oxide metal surface coating is a promising solution to remove heavy metals and other pollutants from drinking water and wastewater. It was reported that metal hydroxide represents a platform for a simple and inexpensive adsorbent capable of removing multiple harmful weak-acid oxyanions in drinking water [9]. It was also suggested that mixing iron particles with sand media may improve the removal of arsenic in solution [10]. Iron, ferric oxide, and iron-based materials have been well-documented as effective adsorbents for As removal from aqueous solution $[10,11]$ or in situ remediations of zinc contaminated groundwater [12]. However, a number of challenges still exist in practice, such as low removal rates, as well as the presence of iron nanoparticles in the water [11].

Optimization of the process parameters, such as $\mathrm{pH}$, sorbent dose, contact time, and temperature, etc., has been undertaken in batch studies. Adsorption isotherms have conventionally been employed for the initial selection before running more expensive experiments. Estimated equilibrium, kinetic, and thermodynamic results can be further used to upscale, design, and operate column reactors.

Due to the information gap for removal efficiency of low-cost removal techniques as mentioned above, this study aimed to investigate a simple $\mathrm{FeOOH}$ coated sand filter for arsenic removal in groundwater. The adsorption of As(III) was investigated as a function of contact time and adsorbent dose. Moreover, adsorption isotherm and kinetic studies were performed to describe the adsorption process. Finally, arsenic-contaminated groundwater containing As(III) was treated by a continuous flow filter column.

\section{Materials and Methods}

\subsection{FeOOH Coated Sand Preparation}

The quartz sand used in this study was sieved to $0.589-1.190 \mathrm{~mm}$ in size. The quartz sand was then coated with amorphous ferric oxyhydroxide ( $\mathrm{FeOOH})$ following the procedure described by Mills et al. (1994) [13]. The sand was heated at $550{ }^{\circ} \mathrm{C}$ for $3 \mathrm{~h}$ and then rinsed several times with DI water to remove organic matter. Trace metals were washed by soaking the sand in concentrated $10 \mathrm{M} \mathrm{HCl}$ for $24 \mathrm{~h}$, then rinsed in $0.01 \mathrm{M}$ $\mathrm{NaOH}$, and finally rinsed with DI water until the effluent $\mathrm{pH}$ reached $8.0 \pm 0.1$. The sand was then oven-dried at $110^{\circ} \mathrm{C}$. The cleaned dry quartz sand was immersed in $400 \mathrm{~mL}$ of $\mathrm{FeCl}_{3}$ solution $\left(50 \mathrm{~g} / \mathrm{L}\right.$ of $\left.\mathrm{FeCl}_{3} \cdot \mathrm{H}_{2} \mathrm{O}, \mathrm{pH} 1.9\right)$, and $30 \mathrm{~mL}$ of $\mathrm{NaOH}(0.5 \mathrm{M})$ was added instantaneously, followed by gradual addition of $1 \mathrm{~mL} \mathrm{NaOH}(0.5 \mathrm{M})$ until the $\mathrm{pH}$ reached between 4.5-5.0. The mixture was then shaken for $36 \mathrm{~h}$ to allow further coating of $\mathrm{FeOOH}$ to the sand grain surfaces. FeOOH coated sand was then rinsed with DI water, air dried, and stored in a clean container for later use. 


\subsection{Batch Study}

A batch adsorption system was conducted in this study. As(III) adsorption experiments were performed by adding $10 \mathrm{~g}$ FeOOH coated sand into a $1 \mathrm{~L}$ beaker containing an As(III) solution of $110 \mu \mathrm{g} / \mathrm{L}$. The beaker was intermittently shaken at $30 \mathrm{rpm}$ with an orbital shaker at room temperature $\left(\sim 300{ }^{\circ} \mathrm{C}\right.$ until pseudo-equilibrium was reached $)$ [8], (2017). The adsorption capacity $(\mu \mathrm{g} / \mathrm{g})$ of the sorbent is defined as the amount of sorbate (As(III)) per unit weight of the sorbent and can be described by using the following mass balance equation:

$$
\mathrm{q}_{\mathrm{t}}=\frac{\left(\mathrm{C}_{0}-\mathrm{C}_{\mathrm{t}}\right) \mathrm{V}}{\mathrm{m}}
$$

where:

$\rightarrow \mathrm{q}_{\mathrm{t}}$ : the amount of adsorbed metal ions of the adsorbent $(\mu \mathrm{g} / \mathrm{g})$,

$\rightarrow \quad \mathrm{C}_{0}$ : the initial concentration of $\mathrm{As}(\mathrm{III})$ in the solution $(\mu \mathrm{g} / \mathrm{L})$

$\rightarrow \mathrm{C}_{\mathrm{t}}$ : the equilibrium concentration of $\mathrm{As}(\mathrm{III})$ in the solution $(\mu \mathrm{g} / \mathrm{L})$

$\rightarrow \quad \mathrm{V}$ : the volume of the medium (L),

$\rightarrow \quad \mathrm{m}$ : the amount of the adsorbent used in the adsorption process (g).

\subsubsection{Adsorption Kinetic Test}

Adsorption kinetics were tested at different time intervals $(0.5,1,2,4,8 \mathrm{~h})$ at neutral pH 7.2 and at an initial concentration of As(III) of $110 \mu \mathrm{g} / \mathrm{L}$. Fixed $10 \mathrm{~g}$ of FeOOH coated sand was added into the beaker, and all the tests were triplicated. The adsorption kinetics were carried out to determine the duration of the experiments that is sufficient to achieve pseudo-equilibrium. During this kinetic experiment, aliquots were sampled at 0.0, 0.5, 1.0, 2.0, 4.0, and 8.0 hourly intervals. Based on the adsorption kinetics test results, a duration of $8.0 \mathrm{~h}$ was decided upon to ensure that pseudo-equilibrium was achieved. Pseudo-first order and pseudo-second-order kinetic models were used to examine the mechanism of adsorption, expressed as the following:

Pseudo-first-order kinetic:

$$
\mathrm{q}_{\mathrm{t}}=\mathrm{q}_{\mathrm{e}}\left(1-\mathrm{e}^{-\mathrm{k}_{1} \mathrm{t}}\right)
$$

Pseudo-second-order kinetic:

$$
\mathrm{q}_{\mathrm{t}}=\frac{\mathrm{q}_{\mathrm{e}}^{2} \mathrm{k}_{2} \mathrm{t}}{1+\mathrm{q}_{\mathrm{e}} \mathrm{k}_{2} \mathrm{t}}
$$

where:

$\rightarrow \quad \mathrm{q}_{\mathrm{e}}$ : the amounts of $\mathrm{As}(\mathrm{III})$ adsorbed at equilibrium, $\mu \mathrm{g} / \mathrm{g}$

$\rightarrow \quad \mathrm{q}_{\mathrm{t}}$ : the amounts of As(III) adsorbed at time $\mathrm{t}, \mu \mathrm{g} / \mathrm{g}$

$\rightarrow \quad \mathrm{k}_{1}$ is the first-order rate constant of adsorption, $\mathrm{g} / \mu \mathrm{g} \cdot \mathrm{h}$

$\rightarrow \quad \mathrm{k}_{2}$ is the second-order kinetic rate constant, $\mathrm{g} / \mu \mathrm{g} \cdot \mathrm{h}$

$\rightarrow \quad \mathrm{t}$ : retention time, hour

\subsubsection{Adsorption Isotherm Study}

Adsorption isotherms were obtained by varying the adsorbent dose $(5,10,20,40$, $80 \mathrm{~g}$ ), while the initial concentration of As(III) was $110 \mu \mathrm{g} / \mathrm{L}$. The equilibrium experiments of the adsorption process were performed after the determination of equilibrium time in order to evaluate the effect of adsorbent mass on As(III) removal. The sorption isotherms were compared graphically against Langmuir and Freundlich models. The Langmuir and Freundlich equations were adapted from Shoppert et al. [12], expressed as the following:

Langmuir isotherm:

$$
\mathrm{q}_{\mathrm{e}}=\frac{\mathrm{q}_{\mathrm{m}} \mathrm{k}_{\mathrm{L}} \mathrm{C}_{\mathrm{e}}}{1+\mathrm{k}_{\mathrm{L}} \mathrm{C}_{\mathrm{e}}}
$$

where: 
$\rightarrow \quad \mathrm{q}_{\mathrm{e}}: \mathrm{As}(\mathrm{III})$ concentration adsorbed on the FeOOH coated sand $(\mu \mathrm{g} / \mathrm{g})$

$\rightarrow \quad \mathrm{C}_{\mathrm{e}}$ : concentration of $\mathrm{As}(\mathrm{III})$ remaining in the solution at equilibrium $(\mu \mathrm{g} / \mathrm{L})$

$\rightarrow \quad \mathrm{q}_{\mathrm{m}}$ : the maximum attainable sorbent capacity, $\mu \mathrm{g} / \mathrm{g}$

$\rightarrow \quad \mathrm{K}_{\mathrm{L}}$ : the Langmuir constant, $\mathrm{L} / \mu \mathrm{g}$

The linear transformation of Langmuir equation:

$$
\frac{\mathrm{q}_{\mathrm{e}}}{\mathrm{C}_{\mathrm{e}}}=\frac{1}{\mathrm{q}_{\mathrm{m}} \mathrm{k}_{\mathrm{L}}}+\frac{1}{\mathrm{q}_{\mathrm{m}}} \mathrm{C}_{\mathrm{e}}
$$

Freundlich isotherm:

$$
\mathrm{q}_{\mathrm{e}}=\mathrm{K}_{\mathrm{F}} \mathrm{C}^{\frac{1}{\mathrm{n}}}
$$

where:

$\rightarrow \quad \mathrm{K}_{\mathrm{F}}$ : Freundlich adsorption cofficient

$\rightarrow \mathrm{n}$ : a dimensionless parameter of Freundlich adsorption intensity

The linear transformation of Freundlich equation:

$$
\ln \mathrm{q}_{\mathrm{e}}=\ln K_{\mathrm{F}}+\frac{1}{\mathrm{n}} \ln \mathrm{C}_{\mathrm{e}}
$$

\subsection{Column Study}

Experimental groundwater was collected from a borehole located in Vinh Long province (Figure 1) using a withdrawn pump (Panasonic 129JXK). Approximately $200 \mathrm{~L}$ of groundwater samples were collected and stored in a $200 \mathrm{~L}$ plastic tank for later use. The properties of the feeding solution consisted of As(III) with the initial concentrations of $81 \mu \mathrm{g} / \mathrm{L}$. The As(III) was artificially added to the groundwater using $\mathrm{NaAsO}_{2}$.

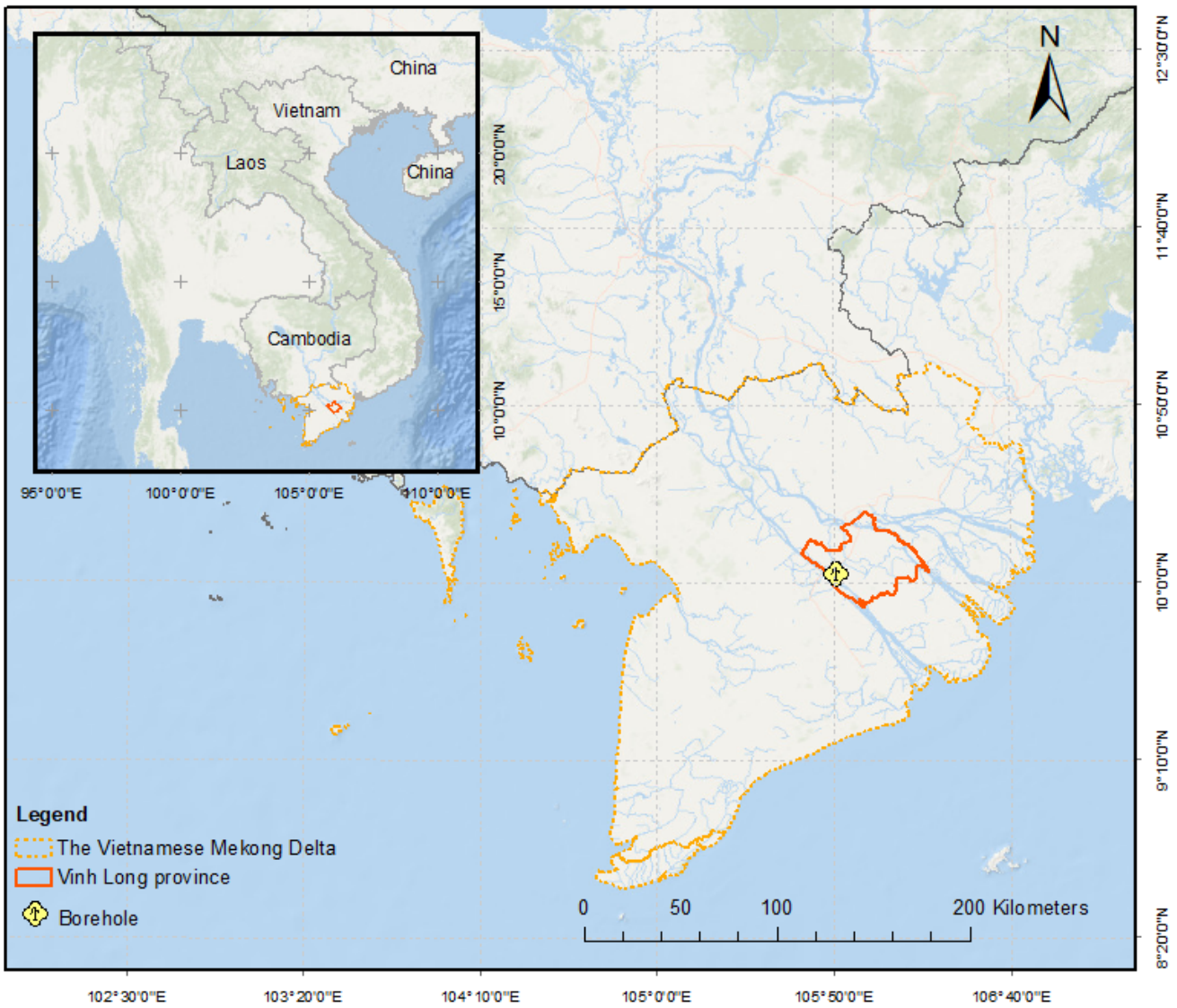

Figure 1. The location of borehole for groundwater extraction. 
Three identical lab-scale columns were designed using $\Phi 42 \mathrm{~mm}$ PVC pipes. The packing media consisted of $\mathrm{FeOOH}$ coated sand. The height of the packing material was $0.7 \mathrm{~m}$ and $0.1 \mathrm{~m}$ of gravel size $3-5 \mathrm{~cm}$. The columns were fed by a multi-channel peristatic pump at flow rates of 10,15 , and $30 \mathrm{~mL} / \mathrm{min}$. The schematic diagram of the filter system is shown in Figure 2.

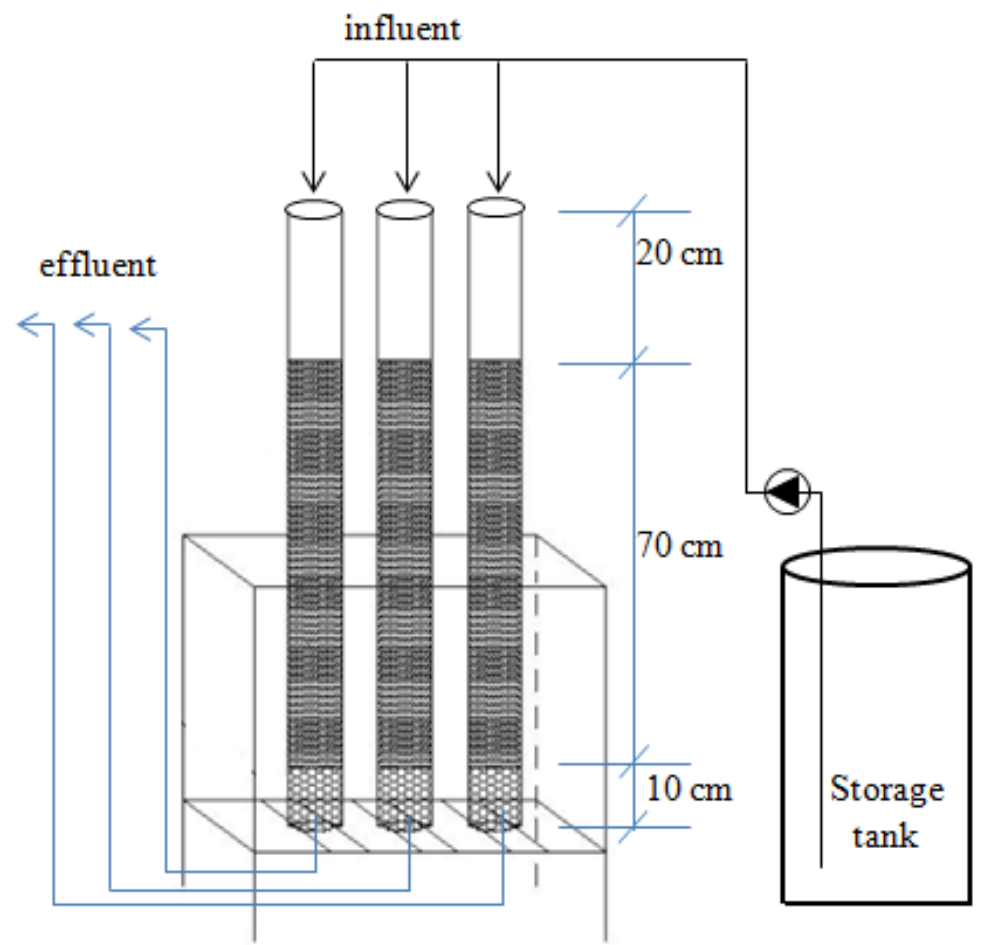

Figure 2. Schematic flow chart of filter column.

The percent sorption ( $\mathrm{R} \%$ ), known as adsorption efficiency, for the As(III) was evaluated from the following equation:

$$
\mathrm{R}=\frac{\left(\mathrm{C}_{\text {in }}-\mathrm{C}_{\mathrm{eff}}\right)}{\mathrm{C}_{\text {in }}} \times 100
$$

where:

$\rightarrow \quad$ R: removal efficiency (\%)

$\rightarrow \mathrm{C}_{\mathrm{in}}$ : the influent concentration of arsenic in the solution $(\mu \mathrm{g} / \mathrm{L})$

$\rightarrow \mathrm{C}_{\text {eff }}$ : the effluent concentration of arsenic in the solution $(\mu \mathrm{g} / \mathrm{L})$

\subsection{Analytical Methods and Data Analysis}

The analytical methods of parameters were carried out according to current standards. Specifically, the $\mathrm{pH}$ and EC were measured using the portable devices Orion 420A and Jenway 4320. Total iron was quantified using the colorimetric method using Jenway Spectrophotometer 6300 at a wavelength of $510 \mathrm{~nm}$. As(III) concentrations in solution were analyzed using inductively coupled plasma mass spectroscopy (ICP-MS Agilent 7700x). Experimental data were analyzed and plotted using MS Excel 2007 and Sigma Plot 10.0.

\section{Results and Discussion}

\subsection{Effects of Contact Time}

The contact time between adsorbate and adsorbent is one of the most important design parameters affecting the performance of the adsorption process. Figure 3A shows the effect of contact time on the adsorption capacity of As(III) onto the iron-coated sand at a concentration of $110 \mu \mathrm{g} / \mathrm{L}$ and $10 \mathrm{~g}$ adsorbent dosage. It can be seen that the uptake 
of $\mathrm{As}$ (III) on FeOOH coated sand was rapid in the first $1 \mathrm{~h}$. The adsorption rate of As(III) gradually decreased between $1 \mathrm{~h}$ and $2 \mathrm{~h}$, mostly reaching equilibrium by the 4 th hour. The removal efficiency by the 4 -hour contact time was $93.6 \%$ (Figure 3B). The gradual decrease in capacity after $1 \mathrm{~h}$ can be due to the reduction of the adsorption sites on the surfaces of $\mathrm{FeOOH}$ coated sand and these sites being already satiated by $\mathrm{As}(\mathrm{III})$ from 4 to $8 \mathrm{~h}$. On the other hand, a large number of surface sites are available for adsorption at the initial time. The remaining surface sites are difficult to occupy because of repulsion between the solute molecules of the solid and bulk phases. Previous studies point out that adsorptive site saturation for arsenic onto iron oxide base materials was obtained after $24 \mathrm{~h}$ of contact time [14]. A faster adsorption rate of As(III) in this study might be due to different adsorbent use. FeOOH coated sand derived from lab chemicals might have a more beneficial effect on the adsorption capacity.
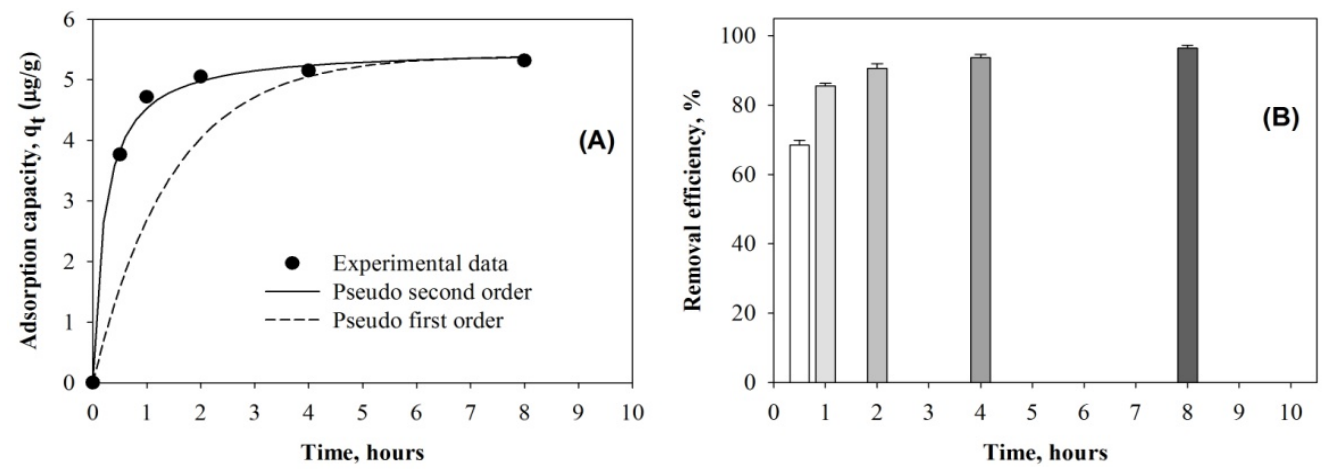

Figure 3. Kinetic study of arsenic adsorption onto FeOOH coated sand. (A) Adsorption capacity; (B) removal of $\mathrm{As}(\mathrm{III})$ by FeOOH coated sand.

\subsection{Adsorption Kinetics}

The results of the kinetic parameters for As(III) adsorption are presented in Table 1. The correlation coefficients of all examined data were found to be very high $\left(R^{2}>0.97\right)$ for pseudo-second-order kinetic. However, the pseudo-first-order kinetic appears to have a low correlation coefficient $\left(R^{2}=0.19\right)$. This result shows that the model can be applied for the entire adsorption process and confirms that the sorption of As(III) onto FeOOH coated sand follows the pseudo-second-order kinetic model. This kinetic study confirmed that adsorption of As(III) onto FeOOH coated sand was a multi-step process involving physical adsorption on the external surface and chemical binding with $\mathrm{FeOOH}$ retained on the sand surfaces (chemical adsorption). This result agrees with previous literature, which outlines that the pseudo-second-order model represents a better adsorption kinetic [12,15]. The previous study revealed that the adsorption mechanism of arsenic on a metal oxide surface was a favorable chemical interaction between adsorbent and adsorbate [11] and permeable adsorptive barriers [12].

Table 1. Kinetic parameters for As(III) adsorption onto FeOOH coated sand.

\begin{tabular}{cccccc}
\hline & Pseudo-First Order & \multicolumn{3}{c}{ Pseudo-Second Order } \\
\hline $\mathrm{k}_{1}$ & $\mathrm{q}_{\mathrm{e}}$ & $\mathrm{R}^{2}$ & $\mathrm{k}_{2}$ & $\mathrm{q}_{\mathrm{e}}$ & $\mathrm{R}^{2}$ \\
0.69 & 5.37 & 0.19 & 0.84 & 5.37 & 0.97 \\
\hline
\end{tabular}

\subsection{Adsorption Isotherm}

The adsorption isotherm of As(III) at an initial concentration of $110 \mu \mathrm{g} / \mathrm{L}$ with different dosages of FeOOH coated sand is shown in Figure 4. The shape of the adsorption curve shows an energetically favorable to adsorb As(III) by FeOOH coated sand. We can see that the Freundlich and Langmuir isotherm equations were well fit to the experimental data. 


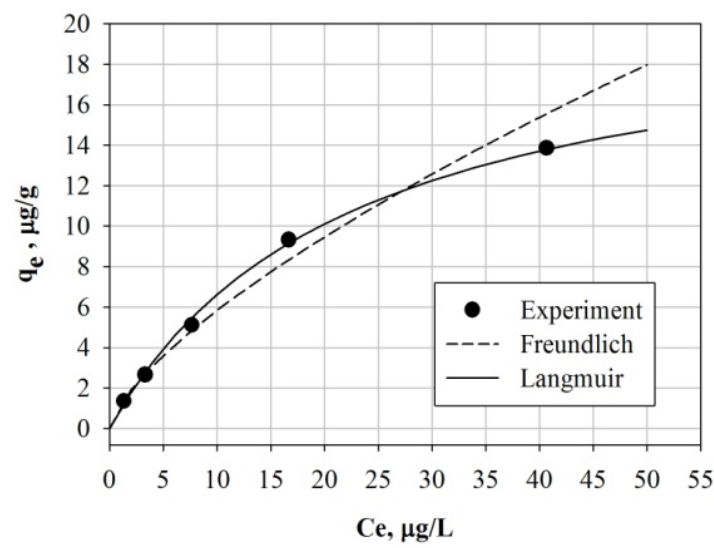

Figure 4. The adsorption isotherm of As(III) onto FeOOH coated sand.

A linear regression analysis of the experimental data was undertaken using Langmuir and Freundlich adsorption isotherm equations (Figure 5). All experimental data points were located within the $95 \%$ confidence interval. The results of the isotherm constants are summarized in Table 2. It can be seen that the correlation coefficients (R) for the Langmuir and Freundlich isotherm model were 0.993 and 0.995 , indicating that the experimental data were well fitted to both isotherms' models. The Langmuir isotherm assumption is a monolayer coverage of As(III) onto the coating surface of the sand with uniform energy and no transmigration of sorbate in the plane of the solid surface. Meanwhile, the Freundlich isotherm is based on the hypothesis of multi-layer sorption. As shown in Table 2, the correlation coefficient of the Freundlich isotherm was greater than that of the Langmuir isotherm for the adsorption of As(III). This suggested that the adsorption of As(III) onto $\mathrm{FeOOH}$ coated sand may be due to the sorption of embedded to the covalent binding and ion exchange between binding sites on the surface of the $\mathrm{FeOOH}$ coated sand. This finding has also been pointed out in previous research [15]. However, another study revealed that Langmuir isotherm is the best fit for heavy metal adsorption onto nanoparticles of iron hydroxide [12]. Our kinetic investigation revealed strong evidence of a multi-step adsorption mechanism of As(III) onto FeOOH coated sand, in which pseudo-second-order was well fitted to the experimental data.
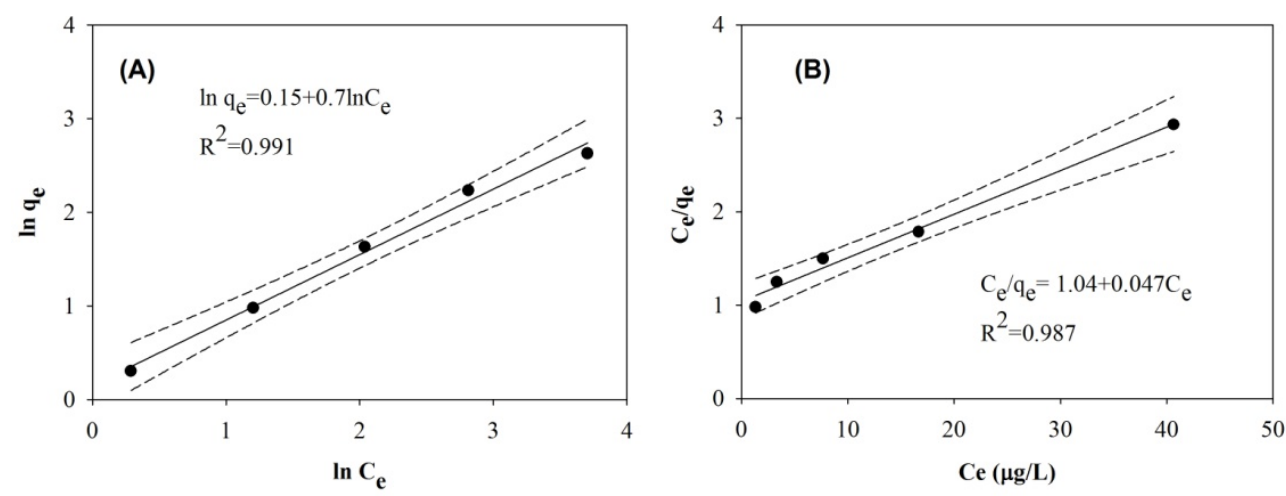

Figure 5. Linear regression of Freundlich (A) and Langmuir (B) isotherms with $95 \%$ confidence interval.

Table 2. Isotherm constants for As(III) adsorption onto FeOOH coated sand.

\begin{tabular}{cccccc}
\hline & Freundlich & \multicolumn{3}{c}{ Langmuir } \\
\hline $\mathrm{n}$ & $\mathrm{K}_{\mathrm{F}}$ & $\mathrm{R}$ & $\mathrm{q}_{\mathrm{m}}$ & $\mathrm{K}_{\mathrm{L}}$ & $\mathrm{R}$ \\
1.43 & 1.16 & 0.995 & 21.3 & 0.045 & 0.993 \\
\hline
\end{tabular}




\subsection{Performance of Filter Column}

In order to contribute to improving community health and disease prevention, a simple water filter column with $\mathrm{FeOOH}$ coated sand media was constructed to treat the groundwater with an influent As concentration of $81 \mu \mathrm{g} / \mathrm{L}$. The experimental results are displayed in Table 3.

Table 3. Influent and effluent As concentration in the column experiment.

\begin{tabular}{|c|c|c|c|c|c|c|c|c|c|}
\hline \multirow{3}{*}{ Parameter } & \multirow{3}{*}{ Unit } & \multirow{2}{*}{\multicolumn{2}{|c|}{ Input }} & \multicolumn{6}{|c|}{ Output of Differenet Flow Rates $(n=5)$} \\
\hline & & & & \multicolumn{2}{|c|}{$10 \mathrm{~mL} / \mathrm{min}$} & \multicolumn{2}{|c|}{$15 \mathrm{~mL} / \mathrm{min}$} & \multicolumn{2}{|c|}{$30 \mathrm{~mL} / \mathrm{min}$} \\
\hline & & Mean & STD & Mean & STD & Mean & STD & Mean & STD \\
\hline $\mathrm{pH}$ & - & 5.1 & 0.1 & 7.5 & 0.2 & 7.3 & 0.2 & 7.4 & 0.3 \\
\hline EC & $\mu \mathrm{S} / \mathrm{cm}$ & 1967 & 15 & 1863 & 21 & 1855 & 16 & 1858 & 29 \\
\hline Turbidity & NTU & 1.35 & 0.13 & 2.9 & 1.56 & 3.0 & 1.68 & 3.4 & 1.93 \\
\hline Total Fe & $\mathrm{mg} / \mathrm{L}$ & 0.122 & 0.0006 & 0.11 & 0.01 & 0.14 & 0.02 & 0.12 & 0.02 \\
\hline $\mathrm{As}(\mathrm{III})$ & $\mu \mathrm{g} / \mathrm{L}$ & 81 & 0 & 1.1 & 0.62 & 1.3 & 0.95 & 1.73 & 0.93 \\
\hline
\end{tabular}

As can be seen in Table 3, the concentration of As(III) reduced from $81 \mu \mathrm{g} / \mathrm{L}$ in the influent to $1.1 \mu \mathrm{g} / \mathrm{L}, 1.3 \mu \mathrm{g} / \mathrm{L}$, and $1.73 \mu \mathrm{g} / \mathrm{L}$ in the effluent, corresponding to flow rates of $10 \mathrm{~mL} / \mathrm{min}, 15 \mathrm{~mL} / \mathrm{min}$, and $30 \mathrm{~mL} / \mathrm{min}$, respectively. This result showed that $\mathrm{FeOOH}$ coated sand filters might be able to remove arsenic in groundwater to meet national drinking water standards.

Figure 6 shows that the As(III) removal efficiency of the FeOOH coated sand filter depends on the flow rates. The higher the flow rates, the lower the arsenic removal efficiency. We can see that the As(III) removal by the filters fed with $10 \mathrm{~mL} / \mathrm{min}, 15 \mathrm{~mL} / \mathrm{min}$, and $30 \mathrm{~mL} / \mathrm{min}$ were $98.9 \%, 98.7 \%$, and $98.3 \%$, respectively. When the filter column had low hydraulic loading, the contact time between the adsorbent and the adsorbate increased. As a result, adsorption rates of $\mathrm{As}(\mathrm{III})$ onto the surface of the $\mathrm{FeOOH}$ coated sand increased. Nevertheless, there was not a significant difference in the removal efficiency of As(III) among these experimental treatments $(p>0.05)$. It was reported that a bio-sand filter with a top layer covered by iron nails was, on average, $92 \%$ effective at removing arsenic [5]. Hsu et al. found that the removal rates of arsenite were much lower than that of arsenate [7]. A high removal rate of viruses was also archived in a study of bio-sand columns amended with nails through an adsorption mechanism [8]. However, limitations of the filter amended with nails include $\mathrm{pH}$, presence of other ions, and long contact time [10]. Increasing $\mathrm{pH}$ solution was not favorable for arsenic adsorption onto iron-coated sand [7]. However, according to Joshi and Chaudhuri, an iron oxide-coated sand column was still effective for arsenate and arsenite removal at $\mathrm{pH}$ 7.5-7.8 [16]. Our results agree with previous studies in which As(III) was removed up to $94 \%$ by a small household configuration of a filter column using iron-coated sand [16]. Thus, this study presents another potential arsenic treatment system, sand coated with $\mathrm{FeOOH}$ prior to use. This system could be applied for small communities and household use with low capital cost and maintenance in the Vietnamese Mekong Delta.

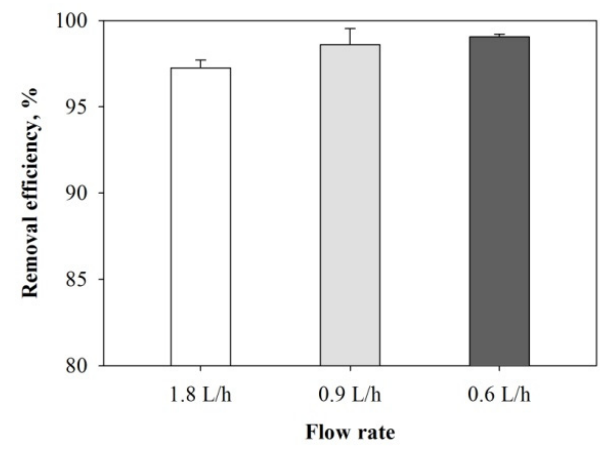

Figure 6. Removal efficiencies of $\mathrm{As}(\mathrm{III})$ in $\mathrm{FeOOH}$ coated sand filter at different flow rates. 


\section{Conclusions}

FeOOH coated sand can be used as an adsorbent to remove Arsenic(III) effectively from water. Kinetics data fitted better for a pseudo-second-order model than a pseudofirst-order model. Arsenic(III) removal efficiency increased with increasing dose of $\mathrm{FeOOH}$ coated sand. Langmuir and Freundlich isotherms were well fit for As(III) adsorption onto FeOOH coated sand surfaces. The maximum adsorption capacity of FeOOH coated sand obtained from the Langmuir model was $21.3 \mu \mathrm{g} / \mathrm{g}$. The column experiment demonstrated that As(III) was removed effectively from $81 \mu \mathrm{g} / \mathrm{L} \mathrm{As}$ (III)-spiked water using FeOOH coated sand media. This is a simple filter that every household could use on their own with a minimum cost of investment and hence has a high future perspective for developing nations with limited resources.

Author Contributions: Conceptualization, L.K. and P.V.T.; methodology, L.K. and N.T.T.; software, L.K. and P.V.T.; validation, L.K., P.V.T., and H.V.T.M.; formal analysis, L.K. and N.T.T.; investigation, L.K., N.T.T.; resources, L.K. and P.V.T.; data curation, L.K., H.V.T.M., and P.K.; writing-original draft preparation, L.K.; writing - review and editing, L.K. and P.K.; visualization, L.K., H.V.T.M., and P.K.; supervision, P.V.T. and P.K.; project administration, P.V.T.; funding acquisition, L.K. and P.V.T. All authors have read and agreed to the published version of the manuscript.

Funding: This research received no external funding.

Institutional Review Board Statement: Not applicable.

Informed Consent Statement: Not applicable.

Data Availability Statement: Not applicable.

Acknowledgments: This study was funded in part by the Can Tho University Improvement Project VN14-P6, supported by a Japanese ODA loan. The authors would like to acknowledge Nigel K. Downes for the language check.

Conflicts of Interest: The authors declare no conflict of interest.

\section{References}

1. Berg, M.; Stengel, C.; Trang, P.; Hungviet, P.; Sampson, M.L.; Leng, M.; Samreth, S.; Fredericks, D. Magnitude of arsenic pollution in the Mekong and Red River Deltas-Cambodia and Vietnam. Sci. Total Environ. 2007, 372, 413-425. [CrossRef] [PubMed]

2. Tran, T.; Tran, K.T.; Vo, M. Research on arsenic pollution in groundwater source in An Phu district, An Giang. J. Sci. Cantho Univ. 2010, 17, 118-123.

3. Le Hoang, V.; Nguyen, H.C.; Huynh, L.T.; Phan, T.T. Treatment of arsenic contaminated groundwater at household scale. J. Sci. Cantho Univ. 2013, 25, 36-43.

4. Erban, L.E.; Gorelick, S.M.; Zebker, H.A.; Fendorf, S. Release of arsenic to deep groundwater in the Mekong Delta, Vietnam, linked to pumping-induced land subsidence. Proc. Natl. Acad. Sci. USA 2013, 110, 13751-13756. [CrossRef] [PubMed]

5. Smith, K.; Li, Z.; Chen, B.; Liang, H.; Zhang, X.; Xu, R.; Li, Z.; Dai, H.; Wei, C.; Liu, S. Comparison of sand-based water filters for point-of-use arsenic removal in China. Chemosphere 2017, 168, 155-162. [CrossRef] [PubMed]

6. Le, S.C.; Mai, T.N.; Nguyen, X.H.; Nguyen, T.H.; Đang, N.T.; Nguyen, T.G.; Tran, Đ.Q.; Nguyen, T.H.H. Evaluation of the ability to treat heavy metals in water using materials made from sludge from iron processing mines. VNU J. Sci.-Earth Environ. Sci. 2016, 2,7 .

7. Hsu, J.-C.; Lin, C.-J.; Liao, C.-H.; Chen, S.-T. Removal of As(V) and As(III) by reclaimed iron-oxide coated sands. J. Hazard. Mater. 2008, 153, 817-826. [CrossRef] [PubMed]

8. Bradley, I.; Straub, A.; Maraccini, P.; Markazi, S.; Nguyen, T.H. Iron oxide amended biosand filters for virus removal. Water Res. 2011, 45, 4501-4510. [CrossRef] [PubMed]

9. Hristovski, K.D.; Markovski, J. Engineering metal (hydr)oxide sorbents for removal of arsenate and similar weak-acid oxyanion contaminants: A critical review with emphasis on factors governing sorption processes. Sci. Total Environ. 2017, 598, 258-271. [CrossRef] [PubMed]

10. Mueller, B.; Dangol, B.; Ngai, T.K.K.; Hug, S.J. Kanchan arsenic filters in the lowlands of Nepal: Mode of operation, arsenic removal, and future improvements. Environ. Geochem. Health 2020, 43, 375-389. [CrossRef] [PubMed]

11. Hao, L.; Liu, M.; Wang, N.; Li, G. A critical review on arsenic removal from water using iron-based adsorbents. RSC Adv. 2018, 8, 39545-39560. [CrossRef] 
12. Krok, B.; Mohammadian, S.; Noll, H.M.; Surau, C.; Markwort, S.; Fritzsche, A.; Nachev, M.; Sures, B.; Meckenstock, R.U. Remediation of zinc-contaminated groundwater by iron oxide in situ adsorption barriers-From lab to the field. Sci. Total Environ. 2021, 807, 151066. [CrossRef] [PubMed]

13. Mills, A.L.; Herman, J.S.; Hornberger, G.M.; DeJesús, T.H. Effect of Solution Ionic Strength and Iron Coatings on Mineral Grains on the Sorption of Bacterial Cells to Quartz Sand. Appl. Environ. Microbiol. 1994, 60, 3300-3306. [CrossRef] [PubMed]

14. Shoppert, A.A.; Loginova, I.V.; Rogozhnikov, D.A.; Karimov, K.A.; Chaikin, L.I. Increased As Adsorption on MaghemiteContaining Red Mud Prepared by the Alkali Fusion-Leaching Method. Minerals 2019, 9, 60. [CrossRef]

15. Jeon, E.-K.; Ryu, S.; Park, S.-W.; Wang, L.; Tsang, D.; Baek, K. Enhanced adsorption of arsenic onto alum sludge modified by calcination. J. Clean. Prod. 2018, 176, 54-62. [CrossRef]

16. Joshi, A.; Chaudhuri, M. Removal of Arsenic from Ground Water by Iron Oxide-Coated Sand. J. Environ. Eng. 1996, $122,769-771$. [CrossRef] 